\title{
Analisis Faktor-faktor yang Mempengaruhi Kinerja Pegawai
}

\author{
Muhammad Rizqi Zati ${ }^{1)^{*}}$, Zulkarnen Mora ${ }^{2)}$, Endang Terangisa BR Sinuraya ${ }^{3)}$ \\ ${ }^{1 *, 2)}$ Program Studi Manajemen, Fakultas Ekonomi, Universitas Samudra \\ e-mail: Rizqi_zati@unsam.ac.id ${ }^{1 *}$
}

\begin{abstract}
Abstrak
Tujuan penelitian ini untuk mengetahui pengaruh Lingkungan Kerja dan Budaya terhadap kinerja pegawai. Penelitian dilakukan di Kantor Pelayanan Pajak Pratama Langsa. Metode penelitian menggunakan metode kuantitatif. Sampel yang digunakan dalam penelitian ini berjumlah 75 responden. Metode analisis data menggunakan regresi linier berganda dengan uji t, uji $\mathrm{F}$, serta analisis koefisien determinasi. Dari analisis data diperoleh persamaan regresi $\mathrm{Y}=2,120+0,341 \mathrm{X}_{1}+$ $0,211 \mathrm{X}_{2}$. Berdasarkan hasil uji t diketahui bahwa Lingkungan kerja berpengaruh signifikan terhadap kinerja pegawai pada Kantor Pelayanan Pajak Pratama Langsa. Budaya kerja berpengaruh signifikan terhadap kinerja pegawai pada Kantor Pelayanan Pajak Pratama Langsa. Berdasarkan hasil uji F diketahui bahwa budaya kerja dan lingkungan kerja secara simultan berpengaruh signifikan terhadap kinerja pegawai pada Kantor Pelayanan Pajak Pratama Langsa. Berdasarkan hasil analisis koefisien determinasi diketahui bahwa Lingkungan kerja dan Budaya kerja mempengaruhi kinerja pegawai Kantor Pelayanan Pajak Pratama Langsa sebesar $20,1 \%$, sementara sisanya $79,9 \%$ dipengaruhi oleh variabel lain yang tidak diteliti dalam penelitian ini seperti gaya kepemimpinan, insentif, dan motivasi kerja.
\end{abstract}

Kata Kunci: Lingkungan Kerja, Budaya Kerja, Kinerja Pegawai

\section{PENDAHULUAN}

Organisasi membutuhkan Sumber Daya Manusia yang berkualitas untuk mencapai tujuannya.

Oleh karena itu, sumber daya manusia harus dapat menunjukkan perannya untuk merealisasikan tujuan organisasi. Organisasi pemerintah merupakan penggerak dalam suatu negara, yang memiliki tujuan untuk mensejahterakan masyarakat. Setiap pegawai di dalam instansi pemerintah harus memiliki kemampuan kerja yang baik dan memiliki semangat yang tinggi sehingga dapat menunjukkan kinerja yang baik. Kinerja pegawai yang tinggi merupakan harapan di dalam organisasi/instansi pemerintah tersebut. Semakin banyak pegawai yang memiliki kinerja tinggi, maka kinerja instansi akan meningkat. Meningkatkan kinerja pegawai yang ada di dalam organisasi dalam hal ini pegawai Kantor Pelayanan Pajak Pratama Langsa merupakan hal yang sangat penting, hal ini dapat berdampak kepada tercapainya visi dan misi organisasi. Kinerja pegawai dipengaruhi oleh banyak faktor salah satunya adalah Lingkungan Kerja.

Setiap organisasi tentu saja memiliki perbedaan dalam lingkungan kerjanya, karena hal ini disesuaikan dengan konsep organisasi masing-masing. Lingkungan kerja diciptakan untuk menunjang kegiatan yang dilakukan oleh pegawai. Dengan adanya lingkungan kerja yang baik maka pekerjaan akan semakin mudah untuk dikerjakan dan membuat semangat kerja pegawai akan meningkat. Winardi 
(2007) menyatakan lingkungan kerja merupakan suatu alat ukur yang akan berpengaruh terhadap kinerja pegawai jika lingkungan kerja yang ada pada instansi itu baik maka akan meningkatkan kinerja pegawai.

Selain Lingkungan kerja, variabel lain yang berpengaruh terhadap kinerja yaitu budaya kerja. Budaya kerja sangat erat kaitannya dalam peningkatkan kinerja pegawai. Dengan terciptanya budaya kerja yang baik dan ditunjang oleh kerja sama yang baik antar sesama pegawai diharapkan dapat memberikan hasil yang baik dalam hal kinerja. Dengan kata lain, budaya kerja yang baik akan memberikan dampak yang dapat meningkatkan kinerja pegawai. Budaya kerja pada umumnya merupakan pernyataan filosofis, dapat difungsikan sebagai tuntutan yang mengikat para pegawai karena dapat diformulasikan secara formal dalam berbagai bentuk peraturan dan ketentuan organisasi. Proses pembentukan budaya kerja yang baik pada akhirnya akan menghasilkan pemimpin dan pegawai professional yang mempunyai integritas yang tinggi.

Kantor Pelayanan Pajak (KPP) Pratama Langsa merupakan unsur pelaksana dibawah Kantor Wilayah Direktorat Jenderal Pajak pada Direktorat Jenderal Pajak yang merupakan salah satu bagian dari Kementerian Keuangan. Tugas pokok KPP Pratama Langsa yaitu melaksanakan penyuluhan, pelayanan, dan pengawasan Wajib Pajak di bidang Pajak Penghasilan, Pajak Pertambahan Nilai, Pajak Penjualan atas Barang Mewah, serta Pajak Tidak Langsung lainnya dalam wilayah wewenangnya berdasarkan peraturan perundang-undangan yang berlaku.

Setiap pegawai KPP Pratama Langsa tentu dituntut untuk memiliki kinerja yang tinggi untuk instansi tersebut. Kinerja merupakan faktor terpenting yang menentukan tercapainya tujuan KPP Pratama Langsa. Berdasarkan pengamatan yang dilakukan telah terjadi penurunan kinerja yang dapat dilihat dari penyelesaian pekerjaan yang terkadang tidak tepat waktu seperti terkait dengan administrasi dan perhitungan pajak perusahaan/instansi tertentu. Hal ini tidak terlepas dari dampak budaya kerja dan lingkungan kerja yang tidak sesuai dan pada akhirnya akan mempengaruhi kinerja pegawai.

Terkait dengan budaya kerja, berdasarkan survey awal yang dilakukan terhadap beberapa pegawai KPP Langsa, mereka mengatakan bahwa budaya kerja di KPP Pratama Langsa perlu ditingkatkan khususnya pada budaya kerja, seperti kurangnya inisiatif pegawai dalam melaksanakan pekerjaan tertentu yang sifatnya berkelompok, begitu juga kerjasama antar pegawai dirasa masih kurang. Padahal kerjasama sangat dibutuhkan di dalam organisasi/instansi. Selain itu dari hasil wawancara awal juga diperoleh informasi bahwa lingkungan kerja bagi beberapa pegawai masih harus dibenahi misalnya kebersihan dan kenyamanan ruangan kerja yang harus ditingkatkan lagi. Adanya konflik personal pegawai di KPP Pratama Langsa juga merupakan salah satu permasalahan yang berkaitan dengan lingkungan kerja yang sifatnya non fisik. Budaya kerja dan lingkungan kerja merupakan faktor yang berpengaruh terhadap kinerja pegawai nantinya. 


\section{TINJAUAN PUSTAKA}

\section{Lingkungan Kerja}

Lingkungan kerja merupakan salah satu faktor penting dalam menciptakan kinerja pegawai yang baik. Lingkungan kerja mempunyai pengaruh langsung terhadap pegawai di dalam menyelesaikan pekerjaan yang pada akhirnya akan berkaitan dengan kinerja mereka. Kondisi lingkungan kerja dikatakan baik apabila pegawai dapat melaksanakan kegiatan secara optimal, sehat, aman, dan nyaman. Karena itu penentuan dan penciptaan lingkungan kerja yang baik akan sangat menentukan keberhasilan pencapaian tujuan organisasi. Sebaliknya apabila lingkungan kerja yang tidak baik akan dapat menurunkan motivasi serta semangat kerja dan akhirnya dapat menurunkan kinerja pegawai.

The workplace environment comprises of various factors that are imperative determinants of employee performance (Lambert, 2001). Lingkungan tempat kerja terdiri dari berbagai faktor yang merupakan penentu dan penting kaitannya dengan kinerja karyawan. McCoy and Evans (2005) the elements of physical work environment need to be proper so that the employees would not be stressed while doing their job (unsur-unsur di dalam lingkungan kerja fisik harus lah tepat sehingga pegawai tidak akan stres saat melakukan pekerjaan mereka)

Kondisi dan suasana lingkungan kerja yang baik akan dapat tercipta dengan adanya penyusunan organisasi secara baik dan benar sebagaimana yang dikatakan oleh Sarwoto (2007) bahwa suasana kerja yang baik dihasilkan terutama dalam organisasi yang tersusun secara baik, sedangkan suasana kerja yang kurang baik banyak ditimbulkan oleh organisasi yang tidak tersusun dengan baik pula. Dari pendapat tersebut dapat diterangkan bahwa terciptanya suasana kerja sangat dipengaruhi oleh struktur organisasi yang ada dalam organisasi tersebut. Menurut Sedarmayanti (2005) menyatakan bahwa secara garis besar, jenis lingkungan kerja terbagi menjadi dua yaitu: lingkungan kerja fisik adalah semua keadaan berbentuk fisik yang terdapat disekitar tempat kerja yang dapat mempengaruhi pegawai baik secara langsung maupun secara tidak langsung. Menurut Komarudin (2006), lingkungan kerja fisik adalah keseluruhan atau setiap aspek dari gejala fisik dan sosial kultiral yang mengelilingi atau mempengaruhi individu. Menurut Nitisimito (2002), lingkungan kerja fisik adalah segala sesuatu yang ada disekitar para pekerja yang dapat mempengaruhi dirinya dalam menjalankan tugas-tugas yang dibebankan, misalnya penerangan, suhu udara, ruang gerak, keamanan, kebersihan, musik dan lain-lain. Menurut Schein (2010), lingkungan kerja adalah "Work environment is a set of characteristics of work conditions that can be measured based on shared perceptions of the members of the organization who live and work together in an organization". Berdasarkan definisi tersebut bahwa lingkungan kerja fisik adalah segala sesuatu yang ada disekitar tempat kerja pegawai lebih banyak berfokus pada benda-benda dan situasi sekitar tempat kerja sehingga dapat mempengaruhi pegawai dalam melaksanakan tugasnya, masalah lingkungan kerja dalam suatu organisasi sangat penting, dalam hal ini diperlukan adanya pengaturan maupun penataan faktor-faktor lingkungan kerja fisik dalam penyelengaraan aktifitas organisasi. 


\section{Budaya Kerja}

Budaya berasal dari bahasa sangsekerta "budhayah" sebagai bentuk jamak dari kata dasar "budhi" yang artinya akal atau segala sesuatu yang berkaitan dengan akal pikiran. Kata budaya merupakan perkembangan dari "budidaya" nilai-nilai dan sikap mental (Kepmenpan No: 25/KEP/M.PAN/04/2002). Budidaya berarti: memberdayakan budi sebagaimana dalam bahasa inggris dikenal sebagai culture yang semula artinya mengolah atau mengerjakan sesuatu, kemudian berkembang sebagai cara manusia mengakutualisasikan nilai (value), karsa (creativity) dan hasil karyanya (performance).

Budaya juga dapat diartikan sebagai keseluruhan usaha rohani dan materi termasuk potensipotensi maupun ketrampilan masyarakat atau kelompok manusia. Slocum dalam West (2000) mendefinisikan budaya sebagai asumsi-asumsi dan pola-pola makna yang mendasar yang dianggap sudah selayaknya dianut dan dimanifestasikan oleh semua pihak yang berpartisipasi dalam organisasi.

Menurut Schein (2010), budaya kerja adalah: "The culture of a group can now be defined as a pattern of shared basic assumtions learned by a group as it solved it's problems of external adaptation and internal integration, which has worked well enough to be considered valid and therefore, to be taught to new members as the correct way to perceive, think, and feel in relation to those problem".

Di Indonesia terdapat perilaku dan sikap budaya yang tercermin dari perilaku dan norma-norma kehidupan sehari-hari, hal ini tidak terlepas dari akar budaya yang dianut masyarakat atau bangsa bersangkutan. Perilaku dan sikap budaya dimaksud ada yang bersifat positif dan ada yang bersifat negatif bila dikaitkan dengan aktifitas dan atau pekerjaan seseorang. Masyarakat Indonesia dikenal memiliki perilaku ramah tamah, budaya gotong-royong, yang sampai saat ini masih sangat dominan terutama di daerah pedesaan.

Selain perilaku dan sikap budaya positif seperti yang digambarkan di atas, rakyat Indonesia juga ditandai dengan perilaku dan sikap yang negatif. Kebiasaan negatif yang seolah-olah merupakan bagian dari kehidupan bersifat kontraproduktif. Beberapa perilaku negatif yang sering terjadi adalah sebagai berikut (Suryadi, 2000).

1. Perilaku tidak disiplin dan tidak jujur.

Hampir semua bagian lapisan masyarakat pada berbagai kasus dan intensitas yang berbeda melakukan tindakan tidak disiplin dan tidak jujur, melakukan pelanggaran hukum/peraturan pemerintah maupun terhadap tugas atau pekerjaan yang menjadi tanggungjawabnya. Perilaku tidak disiplin dan tidak jujur yang dilakukan tersebut akan mempengaruhi kinerja dan berdampak merugikan bangsa dan masyarakat.

2. Perilaku tidak tegas dan tidak percaya diri

Perilaku yang tidak tegas dan tidak percaya diri juga merupakan faktor yang mempengaruhi kinerja seseorang. Orang yang tidak tegas akan selalu berbasa-basi, ragu-ragu dalam mengambil keputusan sehingga akan berakibat buruk bagi keputusan yang menyangkut hajat hidup orang banyak. Tidak percaya diri membuat seseorang tidak mampu berfikir yang berdampak tidak dapat 
mengoperasikan pekerjaanya/ melaksanakan tugasnya secara maksimal dan sebagai implikasinya tujuan organisasi tidak tercapai (Suryadi, 2000).

\section{Kinerja Pegawai}

Prawirosentono (2007) menjelaskan bahwa kinerja merupakan hasil kerja yang dicapai oleh seseorang atau sekelompok dalam suatu organisasi dalam kurung waktu tertentu, sesuai dengan wewenang dan tanggung jawab masing-masing, dalam rangka mencapai tujuan organisasi yang bersangkutan secara legal, tidak melangar hukum dan sesuai dengan moral maupun etika. Seymour (1991), defines performance as the actions done in completing tasks that can be measured (kinerja sebagai tindakan yang dilakukan oleh seseorang dalam menyelesaikan tugas dan dapat diukur). Hal ini dapat berkaitan dengan kuantitas dan kualitas pekerjaan yang dapat diselesaikan oleh individu dalam kurung waktu tertentu. Simamora (2008), kinerja dimaksudkan adalah tingkat terhadap dimana pegawai mencapai persyaratan-persyaratan pekerjaan. Kinerja menurut Casio (1992) performance is a set of results achieved and refers to the act of accomplishment and execution of any work requested; it also refers to the employee achievement on a given task (kinerja adalah seperangkat hasil yang dicapai dan mengacu pada tindakan pencapaian dan pelaksanaan pekerjaan yang diminta; ini juga mengacu pada pencapaian karyawan pada tugas yang diberikan)

\section{Hipotesis}

Hipotesis dalam penelitian ini adalah sebagai berikut:

1. Lingkungan kerja berpengaruh signifikan terhadap kinerja pegawai pada Kantor Pelayanan Pajak Pratama Langsa.

2. Budaya kerja berpengaruh siginifikan terhadap kinerja pegawai pada Kantor Pelayanan Pajak Pratama Langsa.

3. Lingkungan kerja dan budaya kerja secara simultan berpengaruh signifikan terhadap kinerja pegawai pada Kantor Pelayanan Pajak Pratama Langsa.

\section{METODE PENELITIAN}

\section{Jenis Penelitian}

Jenis penelitian ini adalah penelitian asosiatif berdasarkan tingkat eksplanasi (penjelasan). Penelitian asosiatif adalah penelitian yang mencari pengaruh antar variabel dimana dalam penelitian ini adalah pengaruh Lingkungan kerja dan budaya kerja terhadap kinerja pegawai. Lokasi penelitian Kantor Pelayanan Pajak Pratama Langsa. Populasi dalam penelitian ini adalah seluruh pegawai pada KPP Pratama Langsa yang berjumlah 91 orang. Dengan sampel sebanyak 75 orang.

Ada pun jenis data yang digunakan dalam penelitian ini adalah: 
1. Data primer, adalah data mengenai pendapat responden tentang budaya kerja, lingkungan kerja, dan kinerja pegawai yang diperoleh secara langsung dari responden dengan memberikan tanggapan atas pernyataan kuesioner. Di dalam penelitian ini kuesioner dibagikan langsung pada responden.

2. Data sekunder, adalah data yang diperoleh secara tidak langsung melalui perantara. Di dalam penelitian ini, data sekunder hanya mendukung pengumpulan data awal sebagai output peneliti.

\section{Teknik Analisis Data}

Metode analisis data yang digunakan dalam penelitian ini adalah analisis regresi linier berganda. Adapun model matematis dari analisis regresi linier berganda dalam penelitian ini adalah sebagai berikut:

$$
\mathrm{Y}=\mathrm{a}+\mathrm{b}_{1} \mathrm{X}_{1}+\mathrm{b}_{2} \mathrm{X}_{2}
$$

Dimana:

$\mathrm{Y} \quad=$ Kinerja

$\mathrm{X}_{1} \quad=$ Budaya kerja

$\mathrm{X}_{2} \quad=$ Lingkungan kerja

a $\quad=$ Konstanta

$\mathrm{b}_{1}, \mathrm{~b}_{2}=$ Koefisien regresi

Untuk menguji hipotesis, maka digunakan teknik analisis sebagai berikut:

1. Uji t

Digunakan untuk menguji apakah secara individu variabel bebas berpengaruh signifikan terhadap variabel terikat. Hipotesisnya yaitu:

a. Rumusan hipotesis

$\mathrm{H}_{\mathrm{o}}: \beta_{1}=0$, Lingkungan kerja tidak berpengaruh signifikan terhadap kinerja pegawai pada Kantor Pelayanan Pajak Pratama Langsa

$\mathrm{H}_{\mathrm{a}}: \beta_{1} \neq 0$, Lingkungan kerja berpengaruh signifikan terhadap kinerja pegawai pada Kantor Pelayanan Pajak Pratama Langsa

$\mathrm{H}_{\mathrm{o}}: \beta_{2}=0$, Budaya kerja tidak berpengaruh signifikan terhadap kinerja pegawai pada Kantor Pelayanan Pajak Pratama Langsa

$\mathrm{H}_{\mathrm{a}}: \beta_{2} \neq 0$, Budaya kerja berpengaruh signifikan terhadap kinerja pegawai pada Kantor Pelayanan Pajak Pratama Langsa

b. Level of signikansi yaitu: $5 \%$

c. Kriteria pengujian :

Jika nilai t sig. $>$ alpha $(\alpha)=0,05$, maka hipotesis $\mathrm{H}_{\mathrm{o}}$ diterima dan $\mathrm{H}_{\mathrm{a}}$ ditolak

Jika nilai t sig. $<$ alpha $(\alpha)=0,05$, maka hipotesis $\mathrm{H}_{\mathrm{o}}$ ditolak dan $\mathrm{H}_{\mathrm{a}}$ diterima

2. Uji F

Digunakan untuk menguji apakah secara serentak variabel bebas berpengaruh signifikan terhadap variabel terikat. Hipotesisnya yaitu: 
a. Rumusan hipotesis

$\mathrm{H}_{\mathrm{o}}: \beta_{1}: \beta_{2}=0$, Lingkungan kerja dan Budaya kerja secara serentak tidak berpengaruh signifikan terhadap kinerja pegawai pada Kantor Pelayanan Pajak Pratama Langsa

$H_{a}: \beta_{1}: \beta_{2} \neq 0$, Lingkungan kerja dan Budaya kerja secara serentak berpengaruh signifikan terhadap kinerja pegawai pada Kantor Pelayanan Pajak Pratama Langsa

a. Level of signikansi yaitu: $5 \%$

b. Kriteria pengujian :

Jika nilai F sig. $>\alpha=0,05$, maka hipotesis $H_{o}$ diterima dan $H_{a}$ ditolak

Jika nilai $\mathrm{F}$ sig. $<\alpha=0,05$, maka hipotesis $\mathrm{H}_{\mathrm{o}}$ ditolak dan $\mathrm{H}_{\mathrm{a}}$ diterima

3. Koefisien Determinasi $\left(\mathrm{R}^{2}\right)$

Dalam analisis ini terdapat suatu angka yang disebut dengan koefisien determinasi atau yang sering disebut dengan koefisien penentu, karena besarnya adalah kuadrat dari koefisien korelasi $\left(\mathrm{R}^{2}\right)$, sehingga koefisien ini berguna untuk mengetahui pengaruh variabel bebas terhadap variabel terikat. Angka koefisien determinasi berkisar 0 sampai 1. Semakin mendekati nol, maka semakin kecil pula pengaruh semua variabel bebas terhadap variabel terikat. Sebaliknya semakin mendekati 1 maka semakin besar pula pengaruh semua variabel bebas terhadap variabel terikat.

\section{Definisi Operasional Variabel}

Definisi operasional variabel yang digunakan dalam penelitian ini adalah sebagai berikut:

1. Lingkungan Kerja $\left(\mathrm{X}_{1}\right)$

2. Lingkungan kerja adalah segala sesuatu yang ada di sekitar para pekerja yang dapat mempengaruhi dirinya dalam menjalankan tugas yang diemban. Kondisi lingkungan kerja dapat dikatakan baik apabila pegawai dapat melaksanakan kegiatan secara optimal, sehat, aman dan nyaman

3. Budaya Kerja $\left(\mathrm{X}_{2}\right)$

Budaya kerja adalah sistem nilai bersama yang ada didalam suatu organisasi yang menentukan bagaimana para pegawai dalam melakukan pekerjaan untuk mencapai tujuan organisasi.

4. $\operatorname{Kinerja~(Y)}$

Kinerja pegawai merupakan hasil kerja yang secara kualitas dan kuantitas dapat dicapai oleh seorang pegawai dalam melaksanakan tugas sesuai tanggung jawab yang diberikan oleh organisasi tempat dia bekerja.

\section{HASIL DAN PEMBAHASAN}

\section{Analisis Regresi Linier Berganda}

Dalam menguji pengaruh variabel bebas terhadap variabel terikat menggunakan analisis regresi linier berganda dengan hasil sebagai berikut. 
Tabel 1. Hasil Analisis Statistik

\begin{tabular}{|c|c|c|c|}
\hline Variabel & B & $\mathrm{t}$ & Sig. $\mathrm{t}$ \\
\hline Konstanta & 2,120 & 3,775 & 0,000 \\
\hline Lingkungan Kerja & 0,211 & 1,970 & 0,033 \\
\hline Budaya Kerja & 0,341 & 3,459 & 0,001 \\
\hline R. Square & 0,201 & & \\
\hline $\mathrm{F}$ & 9,069 & & \\
\hline Sig. F & 0,000 & & \\
\hline
\end{tabular}

Sumber: Hasil Pengolahan SPSS, 2019

Berdasarkan hasil pada Tabel 1. diperoleh model regresi linear berganda sebagai berikut:

$\mathrm{Y}=2,120+0,211 \mathrm{X}_{1}+0,341 \mathrm{X}_{2}$.

Interprestasi dari persamaan tersebut adalah:

1. Konstanta sebesar 2,120 adalah nilai variabel kinerja apabila variabel Lingkungan kerja dan budaya kerja bernilai 0 (nol).

2. Koefisien regresi variabel lingkungan kerja sebesar 0,211 dan menunjukkan pengaruh positif. Artinya, apabila lingkungan kerja meningkat sebesar satu satuan maka kinerja akan meningkat sebesar 0,211 satuan dengan asumsi variabel budaya kerja tidak berubah (tetap).

3. Koefisien regresi variabel budaya kerja sebesar 0,341 dan menunjukkan pengaruh positif. Artinya, apabila budaya kerja meningkat sebesar satu satuan maka kinerja akan meningkat sebesar 0,341 satuan dengan asumsi variabel lingkungan kerja tidak berubah (tetap).

\section{Pembuktian Hipotesis}

\section{Uji t (Parsial)}

Berdasarkan Tabel 1. maka hasil uji t dapat dijelaskan sebagai berikut.

1. Nilai t sig. variabel lingkungan kerja sebesar 0,033 . Oleh karena nilai $t$ sig. $<$ alpha $(0,033<0,05)$ maka dapat dinyatakan bahwa lingkungan kerja secara parsial berpengaruh signifikan terhadap kinerja pegawai pada Kantor Pelayanan Pajak Pratama Langsa.

2. Nilai t sig. variabel budaya kerja sebesar 0,001 . Oleh karena nilai t sig. $<$ alpha $(0,001<0,05)$ maka dapat dinyatakan bahwa budaya kerja secara parsial berpengaruh signifikan terhadap kinerja pegawai pada Kantor Pelayanan Pajak Pratama Langsa.

Dari uraian di atas maka dapat dinyatakan bahwa hipotesis diterima. Artinya, budaya kerja dan lingkungan kerja secara parsial berpengaruh signifikan terhadap kinerja pegawai pada Kantor Pelayanan Pajak Pratama Langsa. Hasil uji t tersebut sejalan dengan hasil penelitian Pratiwi, dkk (2014) serta Baiquni dan Prihatini (2013) yang menyatakan bahwa budaya kerja dan lingkungan kerja secara parsial berpengaruh signifikan terhadap kinerja. 


\section{Uji F (Simultan)}

Berdasarkan Tabel 1. dapat dilihat nilai F sig. sebesar 0,000. Oleh karena nilai F sig. < alpha $(0,000<0,05)$ maka dapat dinyatakan bahwa Lingkungan kerja dan Budaya kerja secara simultan berpengaruh signifikan terhadap kinerja pegawai pada Kantor Pelayanan Pajak Pratama Langsa. Dengan demikian hipotesis diterima. Hasil uji F tersebut sejalan dengan hasil penelitian Pratiwi, dkk (2014) serta Baiquni dan Prihatini (2013) yang menyatakan bahwa budaya kerja dan lingkungan kerja secara simultan berpengaruh signifikan terhadap kinerja.

\section{Analisis Koefisien Determinasi}

Berdasarkan Tabel 1. dapat dijelaskan bahwa nilai R Square adalah 0,201. Artinya, Lingkungan kerja dan budaya kerja mempengaruhi kinerja pegawai Kantor Pelayanan Pajak Pratama Langsa sebesar $20,1 \%$, sementara sisanya $79,9 \%$ dipengaruhi oleh variabel lain yang tidak diteliti dalam penelitian ini seperti gaya kepemimpinan, insentif, dan motivasi kerja.

\section{KESIMPULAN}

Berdasarkan analisis data dan pembahasan dapat ditarik kesimpulan sebagai berikut:

1. Lingkungan kerja berpengaruh signifikan terhadap kinerja pegawai pada Kantor Pelayanan Pajak Pratama Langsa.

2. Budaya Kerja berpengaruh signifikan terhadap kinerja pegawai pada Kantor Pelayanan Pajak Pratama Langsa.

3. Lingkungan kerja dan budaya kerja secara simultan berpengaruh signifikan terhadap kinerja pegawai pada Kantor Pelayanan Pajak Pratama Langsa.

4. Dari analisis koefisien determinasi diketahui bahwa Lingkungan kerja dan Budaya kerja mempengaruhi kinerja pegawai pada Kantor Pelayanan Pajak Pratama Langsa sebesar 20,1\%, sementara sisanya $79,9 \%$ dipengaruhi oleh variabel lain yang tidak diteliti dalam penelitian ini seperti gaya kepemimpinan, insentif, dan motivasi kerja.

\section{REFERENSI}

Casio, Wayne F. 1992. Managing Human Resources: Productivity, Quality of Worklife, Profits. Singapore: Mc Graw Hill International Editions.

Hasil Keputusan Sidang Sinode XXVI di Tiga Sudara 17-22 Juni 2007 dalam Visi Misi. Hal: 184.

Komarudin. 2006. Perilaku dan Budaya Organisasi. Cetakan Kedua. Bandung: Refika Aditams.

Lambert, E. G., Hogan, N. L. and Barton, S. M. 2001. The Impact of Job Satisfaction on Turnover Intent: a Test of Structural Measurement Model Using a National Sample of Workers. Social Science Journal. Vol. 38. Hal: 233-251.

McCoy, J. M., and Evans, G. W. 2005. Physical Work Environment. In: J. Barling.

Nitisemito, Alex, S. 2002. Manajemen Personalia. Jakarta: Ghalia Indonesia.

Prawirosentono. 2007. Manajemen Mutu Sumber Daya Manusia. Cetakan Pertama. Jakarta: Ghaliaindonesia.

Schein, Michael. 2010. Manajemen Sumber Daya Manusia. Bandung: Alfabeta.

Seymour, J. Madison. 1991. AID University Linkages for Agricultural Development. Journal of Higher Education. Vol. 62 No. 3. Hal: 288-316.

Sugiyono. 2012. Metode Penelitian kuantitatif kualitatif dan R\&D. Bandung: Alfabeta. 
Sedarmayanti. 2005. Tata kerja dan Produktifitas Kerja. Bandung: Penerbit Mandar maju. Simamora, Hendry. 2008. Manajemen Sumber Daya Manusia. Yogyakarta: STIE YKPN.

Suryadi. 2000. Evaluasi Kinerja. Bandung: Refika Aditama. 